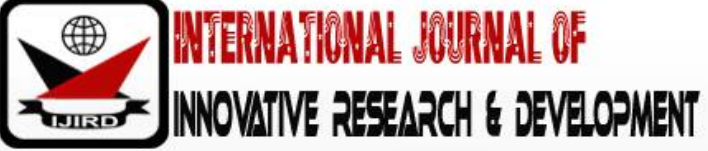

ISSN 2278 - 0211 (Online)

\section{Male Participation in the Catering Industry in Kasoa, Ghana}

\author{
Dr. Faustina Kwakye \\ Dean, School of Business, West End University College, Ghana
}

\begin{abstract}
:
The main objective of the study was to examine the participation of males in the catering industry in Kasoa. Snowballing method was used to select 27 employers, 52 employees and 52 sole proprietors dealing directly with food provision. Pre-tested structured interview guide, with both closed- and open-ended items, were used to collect data, which were coded and analyzed using SPSS software. The main findings were that only 29 out of the 131 respondents had had the requisite training in catering and $53.6 \%$ of them worked as chefs and cooks, dished out food and prepared pastries. The choice of catering by the males was found to have been influenced mainly by economic factors, relatives and interest. It was again found out that strenuous activities in the selected establishments were performed by those males who had low educational levels. Parents, teachers and Guidance and Counselling Coordinators in schools should avoid restricting males to specific courses leaving out catering and sewing.
\end{abstract}

Keywords: Male participation, catering, occupational choice, interests, stereotypes

\section{Introduction}

It is generally believed that programmes and career choices seem to have been constructed by the gender-role stereotypes or perceptions of roles which most societies consider appropriate for boys. The traditional gender roles have been reinforced by parents, the community, the school, peers, the working environment and the mass media (Bierstedt, 2000). The author posited again that these stereotypes have been so emphasized to an extent that they have modelled masculine and feminine behaviour and have resulted in the in modern apprenticeships placement to be genderstereotyped pattern (Bierstedt, 2000). Stereotyping also reflects the way men and women are socialized in their families and these epitomize the gendered nature of their society. Perera and Velummayilum (2008) observed that, according to theories on gender, roles and work, masculinity is characterized traditionally as dominance and competitiveness, while, in contrast, women select careers that have regular hours of work to enable them to fulfill family obligations. The foregoing argument buttresses the fact that career choices are usually a product of one's socialization since society's gender role socialization determines what roles males and females should aspire (Watt, \& Eccles, 2008; Watt, 2010).

Different structural roles of men and women in the market economy are coupled with their equally different and unbalanced roles in the household economy. The boundaries between economic and household chores of men are largely in income-generating activities because those are largely the roles society prescribed for them (Blood \& Wolfe, 1997). Hardiman (1990) also added that roles are unambiguously defined in the Ghanaian traditional family system. Although there are ethnic variations in the help men give to their wives, the traditional Ghanaian woman or wife is typically the homemaker or bearer of children. Household tasks such as cooking, dish washing, sweeping, feeding the family, fetching water, childcare, marketing, laundry and general cleaning of the house are the sole duties of wives (Hardiman, 1990). The traditional gender roles have been reinforced by parents, the community, the school, peers, the working environment and the mass media. These stereotypes have modelled masculine and feminine behaviour, making the pattern of placement in modern apprenticeships to be gender-stereotyped (Bierstedt, 2000).

Ilahi (2000) observed that although nature determines an individual's sex, culture determines the attitudes and behaviours appropriate for an individual on the basis of his or her sex. In each culture therefore individuals learn to adapt to these expectations as they shape their personal and professional lives. Role expectations of men and women differ from family to family due to cultural background of the people involved. In the industrial society, roles of men and women are not so clearly defined. According to Connel (1997), in the typical African homes, a man, as a husband, is expected to provide a home and security; a means of subsistence to meet the financial needs of the family members and so this has had various influences on most African societies. There are different structural roles of men and women in the market economy and they are usually coupled with their equally different and unbalanced roles in the household economy. The boundaries between economic and household chores of men are largely in income-generating activities because those are largely the roles society prescribed for them (Blood \& Wolfe, 1997). Androgyny, which refers to the blending of traditional masculinity and feminity in the same individual, was proposed to bridge the gap between masculinity and feminity (Cook, 1995). To Cook, an integration of the two is hoped to make individuals free to create a personality based on their own personal needs and beliefs, an essential element of personal development. The argument put up so far, buttresses the fact 
that career choices are usually a product of one's socialization since society's gender role socialization determines what roles males and females should aspire.

Studies by Lave and Wenger (1993) and Eccles (1996), cited by Grandfield (1996), found out that parental influence on the choice of occupations by their children was quite strong. Boys are conditioned from childhood in numberless ways to be more effective physically than girls. They are in activities that develop muscles, they are taught to place their weight firmly on both feet, to move freely, to move their bodies with authority. Granfield (1996) also explained that nurture could bring about biological changes, which in turn are thought of as innate tendencies. Similar studies in Ghana conducted by ILO/JASPA (1993) confirmed these findings and concluded that females were concentrated in distribution, hotel and catering and the services.

Watt and Eccles (2008) argued that men and women tend to end up in different kinds of occupations, a phenomenon which is extraordinarily robust across different settings, although there is certainly also cultural variation. Concerns regarding gendered occupational participation have often focused on women's underrepresentation in STEM (Science, Technology, Engineering, Mathematics) domains based on arguments related to gender equity (Watt, 2010).

Although men have been penetrating into traditionally female-dominated professions, gender differences persist. Why does a gender imbalance remain, and does it matter? Both genders in male-dominated, masculine-typed occupations report higher levels of job satisfaction than both genders in female-dominated, feminine-typed occupations (Jacobs, Chhin., \& Bleeker, 2006). (Watt, 2010) citing from Moore (1985) indicated that a possible explanation could be that maledominated occupations generally provide higher levels of income, freedom, and challenge than female-dominated occupations do.

The second argument put up by (Watt, 2010) is concerned with social equity and individual well-being. Gender differences in earning potential are important because women are more likely than men to be single, widowed, or single heads of households; therefore, those women are likely to need to support themselves and their dependents financially (Meece, 2006, cited by Watt, 2010). Also, both women and men need to develop and deploy their talents and abilities in their work outside the home, as developing and using one's abilities in the workplace substantially impacts general life satisfaction and psychological well-being (Meece, 2006). Watt (2010)

Studies of factors affecting female students' career choices and aspirations, found numerous factors, ranging from gender-socialized roles and perceptions of careers considered appropriate for girls and boys or women and men. The study also concluded that gender socialization coupled with teacher attitudes, parental expectations and the influence of peers had an influence on career options of adolescents (Watt, \& Eccles, 2008). Through gender role socialization, girls and boys tend to acquire early beliefs about their social roles, which have been found to exert significant influences on their education and career aspirations and choices. Watt (2010) again listed several factors that are likely to influence adolescent career choices greatly. These include barriers and supports, parents, peers, teachers, the media, perceived and real abilities and motivations. On barriers and supports, she posited that they affect career choices indirectly via their impact on individual self-efficacies and interests. On parental influence Watt (2010) cited from Chhin, Jacobs, Bleeker, Vernon, and Tanner (2005) that parental educational expectations for their children during adolescence relate to their adult children's actual educational attainment, which in turn often end up influencing career choices. Since adolescents spend more time with peers than families and less with parents, they tend to follow peers in their choices. The media also contributes a lot to what jobs the society regard as acceptable. Perceived and real abilities also dictate adolescents' choice of careers. To Smith (2000), in most homes' children take up skills of home management from the family. Smith argued that even though there are several prominent men in the culinary field, specifically, their first teachers were their mothers. In a contribution by Narayan (2001) on the issue in an article "Where the kitchen is mostly a man's club" to New York Times, page 23, Narayan contended most fast and food preparation workers required little education or training since the skills of these workers is learnt and through constant practice on the job, mostly at the workplace.

As far back as 1989, Nweke and Anabgogu found out from their studies that there were both external and internal factors that influenced the carrier choices of the students they studied. The external factors included self-concept, aptitudes and intellectual and physical abilities. The internal factors included, educational level, parental and peer pressure, school influences, prestige of the job as well as the economic and political conditions. Chrisler and McCreary's (2010), contribution on the factors influencing occupational choices by adolescents argued that the factors could be put in three levels, which include: i.) Structural (economic, policy, etc.) , ii) Institutional (Curriculum, teacher quality, teacherstudent relationship) and iii) Individual levels (Gender, identity/ self-concept/values, personality, motivation, ethnicity, socioeconomic status, literacy/numeracy levels and peers, parents, media). Interest was also found to be a motivating factor in occupational choice of adolescents by Smith and White (2007).

History has it that men entered the public culinary profession, first by being assigned to feed their fellow soldiers, then honing their craft and eventually claiming cooking as their profession (Mackenzie, 1997). According to Banner (1999), it is now accepted that most of the world's top chefs are men. Chefs and cooks create recipes and prepare meals in various establishments. A woman's place is in the kitchen, goes the old-fashioned saying but when it comes to hotels and restaurants, more-often-than not, the opposite is true (Point, 1990; National Restaurants Association, 2003). The association strongly believes that male chefs far outnumber their female counterparts in most parts of the world. Mackenzie (1997) is also of the view that currently, men have taken over the position of chefs in hotels and restaurants.

When the picture is centred on Ghana, it is observed that several catering establishments have sprung up over time. From Wikipedia, the free encyclopedia, it is reported Kasoa, formerly known as Odupongkpehe, is a peri-urban town in the Awutu Senya East Municipal District of the Central region of Ghana. Kasoa is the headquarters of Awutu Senya East Municipal Assembly (ASEMA). Today, Kasoa is home to several ethnic groups. 
Kasoa used to be a rural community; but has now urbanized very rapidly. According to Nyasulu (2012), Ghana has experienced rapid population growth in the past three decades. The population growth directly affects Kasoa, which is now reported to be one of the fastest growing communities in West Africa (Yankson, 2012). It is also revealed in the National Analytical Report (exploringafrica.matrix.msu.edu.) that the net population growth between 1970 and 2010 is 68,521. Again, in the past 40 years Kasoa's population has increased more than 79 times what it was in 1970. In the same report is believed that since 2000, the "spill-over effect" of the growing population of the Accra-Tema metropolitan area into smaller towns around the edges has contributed greatly to the rapid increase in the populations of towns, like Kasoa (Awutu-Senya East Municipal Assembly, 2014). It can be observed from the study area that a lot of males and females have found employment in the catering industry in Kasoa. Almost all of the big and small hotels, restaurants, modern or traditional in Kasoa have male employees who are directly connected with the kitchen and meal preparation. However, as Oppong (1999) has noted, the participation of males in catering has been very minimal and the pattern has not changed much over the years in Ghana. Observation and general comments from people who patronize the catering establishments in the study area do give credence to Oppong's assertion. To buttress this assertion, in a study by MacArthur on compliance with food safety measures by traditional caterers in the Cape Coast metropolis in 2008, she found out that out of the 100 traditional caterers in the sample only $17.0 \%$ were males, thus confirming that the number of males working in catering establishments in the metropolis is rather very low. Questions bothering individuals as when and how to change perspectives of pupils and parents as well as teachers in order to provide them with a view of the work place that challenges traditional attitudes and patterns and the traditional perceptions of men's jobs and women's jobs, still remain unanswered.

\section{Statement of the Problem}

The very rapid population growth leading to the urban sprawl has had very specific and identifiable effects on Kasoa (Awutu-Senya East Municipal Assembly, 2014). One of the prominent effects of this sprawl has been the need to feed the teeming population of Kasoa. This need has resulted in several catering establishments that have and continue to spring up in Kasoa. Thus, the participation of males in the industry will equally be expected to grow.

Several hotels, restaurants and food joints are seen at every corner with both male and female operators. They deal with khebabs, grilled tilapia, liver, beef chicken as well as fried rice. These males are also found operating in food joints that are traditionally considered as preserves for females. Since some males can continually be found in the catering establishments participating in the provision of meals for people (MacArthur, 2008), it may be signifying that role expectations of the society probably seem to be diminishing.

The problem does continue to exist in our first, second as well as tertiary educational establishments in Ghana. The number of males in Home Economics and Catering programs are still quite low. For example, Amoamah, Brew, Ampiaw, and Dadzie (2016) in their study reported that students in Hotel, Catering and Institutional Management programme (Accra Polytechnic), were as follows: 16 males/ 115 females in the 1st year; 15 males/ 110 females in $2^{\text {nd }}$ year and 8 males/ 74 females in the $3^{\text {rd }}$ year. It is also observed that a number of males have graduated from second cycle and tertiary cycle institutions and are yet to find jobs. Some of them have found themselves in the catering industry as their last resort. Male participation in the industry will equally be expected to grow as jobs continue to diminish. Since males continue to be found in the catering establishments, people often wonder and ask questions such as: Who are these males? What has influenced such unconventional occupational choice? What activities specifically do they undertake in the catering establishments? How do they enjoy their work? How do they perceive themselves and their occupations as males? What is the perception of the employers about these males? Studies about males in the catering occupations in Ghana are very few and so this study was carried out to primarily to answer these and other questions often asked.

The world of work has been impacted by demographic changes within the workforce, emerging technologies, an increasingly globalized economy, and decreased employment security (Fouad, 2007).Rapid changes in the economy and labour force have created a world of work that is now geared towards which abilities and values will be the most valuable for individuals to function effectively and continues to be important concerns in this changing environment (Fouad, 2007).

\section{Research Questions}

The purpose of the study was to examine the participation of males in the catering industry in Kasoa. To achieve this purpose, the following research questions were formulated:

- What are the demographic characteristics of the males in terms of age at the start of the job, educational level, marital status, training relating to catering and years of experience in the catering industry in Kasoa?

- What factors influenced the choice of occupation in catering by these males?

- What specific roles do these males play in the catering establishments in Kasoa?

- What are views of the selected males on male participation in the catering industry?

\section{Methodology}

The descriptive cross-sectional survey research design was used since it enabled a good examination and accurate description of the activities of the males in the industry (Amedahe, 2005; Stangor, 2014). A mixed method approach, consisting mostly of quantitative and a limited number of qualitative methods were used.

\subsection{Target Population}

The target population comprised of all employers in the study area who had male employees, and male operators of catering establishments in Kasoa. It was very difficult to get the number of males working in catering establishments in 
Kasoa since most of them were found to be casual workers. Again, apart from those working in the hotels, several of them worked mostly late in the evening and in night which is rather dangerous for data collection in the streets of Kasoa. The numbers in the other establishments were also not known and so there was no sample frame.

\subsection{Sampling Procedure and Sample}

Snowballing, starting with two fast food joint operators, was used to get male operators of fast food and khebab joints, male employees from hotels, restaurants and traditional catering establishments, and male employers in small and medium size hotels, restaurants and beer bars which serve cooked meat. At the end of the exercise, 131 male respondents, comprising of 27 employers, 52 employees and 52 self-employed, who were found to be willing to take part in the study were identified.

\subsection{Instrumentation}

Structured interview guide, consisting of both closed- and open-ended items, was prepared based on the research questions. The close-ended section was for information on respondents' personal data, factors influencing choice of occupation and the open-ended questions focused on the views of the respondents on the participation of males in the catering industry. Likert scale, with the response categories ranging between two extreme positions and divided into a four-point scale with the rating from, Strongly Disagree (1), Disagree (2), Agree (3), and Strongly Agree (4) was employed to get data on reasons for choice of occupation.

\subsection{Data Collection}

The interview guide was prepared and pre-tested using ten males in catering establishments in and around Opeikuma Junction at Kasoa to remove ambiguities and to make the understanding easy. Permission was sought from the heads of the establishments selected. Each of the respondents was first made aware of the purpose of the study and also assured of the confidentiality of the information collected. The respondents were interviewed at their workplaces, with each interview lasting for about 30 minutes. The data collection was completed in seven days. Only those who were willing and ready to participate were involved in the study.

\subsection{Data Analysis}

Data were coded and analyzed using SPSS (17.0 version) and presented by frequency distribution and means. Mean scores were used to analyze the data on the factors influencing occupational choice. The mean score for the fourpoint scale was 2.50 so all mean scores from the analysis which were greater than 2.50 indicated acceptance of the statement by the respondents and the mean scores below 2.50 indicated rejection of the statement.

\section{Results and Discussion}

The personal data of the respondents comprised age at the start of occupation, years of working experience, educational level and marital status. Table 1 shows the background characteristics of the respondents.

\begin{tabular}{|c|c|c|}
\hline Characteristic & Frequency (No = 131) & Percentage \\
\hline Age at the Start of Occupation & 24 & 18.3 \\
Below 20 years & 57 & 43.5 \\
20 - 24 years & 35 & 26.7 \\
25 - 29 years & 15 & 11.5 \\
Above 30 years & 16 & 12.2 \\
Years of Working Experience & 82 & 62.6 \\
Below 1 year & 11 & 8.4 \\
1 - 5 years & 19 & 14.5 \\
6- 10 years & 3 & 2.3 \\
11 - 15 years & 2 & 1.5 \\
16- 20 years & 80 & 61.1 \\
Educational Level & 14 & 10.6 \\
No formal education & 12 & 9.2 \\
Basic school & 10 & 7.6 \\
Vocational School & 13 & 10.0 \\
City and Guilds & & \\
Senior High School & 58 & 44.3 \\
Tertiary & 73 & 55.7 \\
Marital Status & 0 & 0 \\
Single (Never married) & & \\
Married &
\end{tabular}

Table 1: Demographic Characteristics of Respondents

Source: Field Survey, 2016 
The results of the analysis of the characteristics, as presented in Table 1, reveals that the majority, $70.2 \%$ of the respondents interviewed, took up careers in the catering industry when they were aged between 20 and 29 years. Data on years of working experience also indicate that $62.6 \%$ of the respondents had been working in the catering industry for periods between one and five years. Thirty of them (22.9\%) had between 6 and 15 years of working experience. Sixteen $(12.2 \%)$ had been in the job just a couple of months before the study. The fact that the majority (70.2\%) of the respondents interviewed took up careers in the catering industry when they were aged between 20 and 29 years was not surprising. This is because between the ages below 20 years, a number of them would still be in school, or in apprenticeships. The respondents in this study were therefore old enough to make their own decisions.

Analysis of the question on educational level indicated that two $(1.5 \%)$ of the respondents had no formal education. The rest, 129 (98.5\%) had received formal education but only 49 (37.4\%) of them had gone beyond the basic level. The details are: 80 (61.1\%) had basic education, 14 (10.6\%) with Vocational school certificate, 12 (9.2\%) obtained City and Guilds certificate, 10 (7.6\%) had Senior High School certificate. Twenty-nine respondents had had training in catering and related courses since they had chosen to work in catering establishments. They comprised three from the polytechnics, 14 from the vocational schools and 12 of them with City and Guilds.

It was also found out that $73(55.7 \%)$ of the respondents were married and were with their spouses at the time of the study, while the remaining 58 (44.3\%) had never married. There was no divorced, separated or widowed respondent among the sample.

\subsection{Factors Influencing Respondents' Choice of Occupation}

The respondents were asked to state the main reason why they chose to work in the catering industry, on a scale of 1 - 4; 1 being Strongly Disagree (SD), 2 being Disagree (D), 3 being Agree (A) or 4 representing Strongly Agree (SA) varied responses were given. Table 2 presents the analysis.

\begin{tabular}{|c|c|c|c|c|c|}
\hline $\begin{array}{l}\text { Factors Influencing } \\
\text { Choice }\end{array}$ & $\begin{array}{l}\text { Strongly Disagree } \\
\text { Disagree }\end{array}$ & Agree & $\begin{array}{l}\text { Strongly } \\
\text { Agree }\end{array}$ & Mean & $\begin{array}{l}\text { Standard } \\
\text { Deviation }\end{array}$ \\
\hline & $\begin{array}{ll}\text { No(\%) } & \text { No(\%) }\end{array}$ & No(\%) & No(\%) & & \\
\hline To earn a living & $\begin{array}{ll}9(6.9) & 18(13.7)\end{array}$ & $61(46.6)$ & $43(32.8)$ & 3.05 & 0.862 \\
\hline $\begin{array}{l}\text { Influence from } \\
\text { relative }\end{array}$ & $43(23.8)$ & $37(30.6)$ & $38(42.0)$ & 2.76 & 0.983 \\
\hline Interest in cooking & $23(17.6)$ & $36(27.4)$ & $8(29.0)$ & 2.68 & 1.076 \\
\hline $\begin{array}{c}\text { Influence by school } \\
\text { courses }\end{array}$ & 18(13.7) & $60(45.8)$ & $19(14.5)$ & 2.61 & 0.899 \\
\hline $\begin{array}{l}\text { Past experience in } \\
\text { the job }\end{array}$ & $40(30.5)$ & $36(27.5)$ & $4(18.3)$ & 2.40 & 1.044 \\
\hline $\begin{array}{l}\text { The joy of being self- } \\
\text { employed }\end{array}$ & $50(38.2)$ & $24(18.3)$ & $5(11.5)$ & 2.09 & 0.890 \\
\hline Friend's influence & $52(39.9)$ & $15(11.5)$ & $8(6.1)$ & 1.84 & 0.858 \\
\hline
\end{tabular}

Table 2: Factors Influencing Respondents' Choice of Occupation

Source: Field Survey, 2016

The responses to the statement that the respondents selected catering in order to earn a living had a mean of 3.05 and a standard deviation of 0.862. Influence from relatives, had a mean of 2.76 and a standard deviation of 0.983 . Interest in catering was the third influence for the choice of catering by the respondents with a mean of 2.68 and a standard deviation of 1.076. The general mean for the reason that the respondents chose catering owing to the influence from courses taken in school was 2.61, the standard deviation being 0.899 . All these four statements had means greater than 2.50 , signifying agreement by respondents.

The three statements with their means less than 2.50 were influence from past experience in the job, the joy of being self-employed and influence from friends. The mean from influence from past experience in the job was 2.40 and a standard deviation of 1.044. The joy of being self-employed had a mean of 2.09 with a standard deviation of 0.890 and influence from friends also had a mean of 1.84 with a standard deviation of 0.858 .

The respondents agreed that they selected catering in order to earn a living. This was the statement with the highest mean of 3.05, followed by the influence of relatives with a mean of 2.76. It is generally common that people are driven by economic reasons to take up jobs in any field. The finding is supported the assertion by Blood and Wolfe (1997) that boundaries between economic and household chores of men are largely in income-generating activities because those are largely the roles society prescribed for them. Men will be driven more by economic factors since they are supposed to be the bread winners in the family.

The results revealed that influence from relatives was the second major factor influencing the choice of catering by the males. In most homes' children take up skills of home management form the family (Smith, 2000). Further examination of the responses indicated that 38\% of the influence was by female relatives, confirming Smith's (2000) argument which specifically stated that even though there are several prominent men in the culinary field, their first teachers were their mothers and relatives.

Interest in catering was the third influence for the choice of catering by the respondents with a mean of 2.68. This is heartwarming to find out that despite the stereotyping attached to males in catering, some males still have interest in the profession. The respondents were also in agreement with the statement that courses taken at school influenced their choice 
of catering. The general mean was 2.61, which is higher than 2.50. When it was noticed from the trend in the responses that only 29 of them had training in catering, the respondents were asked how they got to be conversant with the courses. They replied that it was through friends although they did not agree initially with the statement that their choice of catering was influenced by friends.

The three statements with the means less than 2.50 were influence from past experience in the job, the joy of being self-employed and influence from friends. These means indicated that the respondents disagreed with the three statements, which was somehow surprising since these were part of the listed reasons given by the respondents earlier on. Obviously, the numbers and weight given to these reasons were not high enough to warrant agreement by the total sample. Although most of them did not have any training in catering and they attributed their choice to friends, it is the statement that had the lowest mean of 1.84 .

The reasons for the choice of occupation in catering are in line with the assertion by Nweke and Anabgogu's (1989), who conceptualized that occupational choice, is influenced by both internal and external factors. However, the only internal factor identified in this study was interest. This finding supports the study by Nyamwange (2016), Vosh and Schauble (2014), and Singh, Granville, and Dika (2002) also found out that influence of student's interest on career choice was quite significant. The other reasons were external and they were economic influence, influence from relatives particularly females and school courses. These also support the assertions by Meece (2006) and Watt (2010) that both women and men need to develop and deploy their talents and abilities in their work outside the home, as developing and using one's abilities in the workplace substantially impacts general life satisfaction and psychological well-being.

\subsection{Specific Roles Performed by the Respondents in the Various Establishments}

This section concentrates mainly on the specific duties the males performed in the catering establishments where they worked. A number of the respondents were involved in more than one activity, hence, the multiple responses.

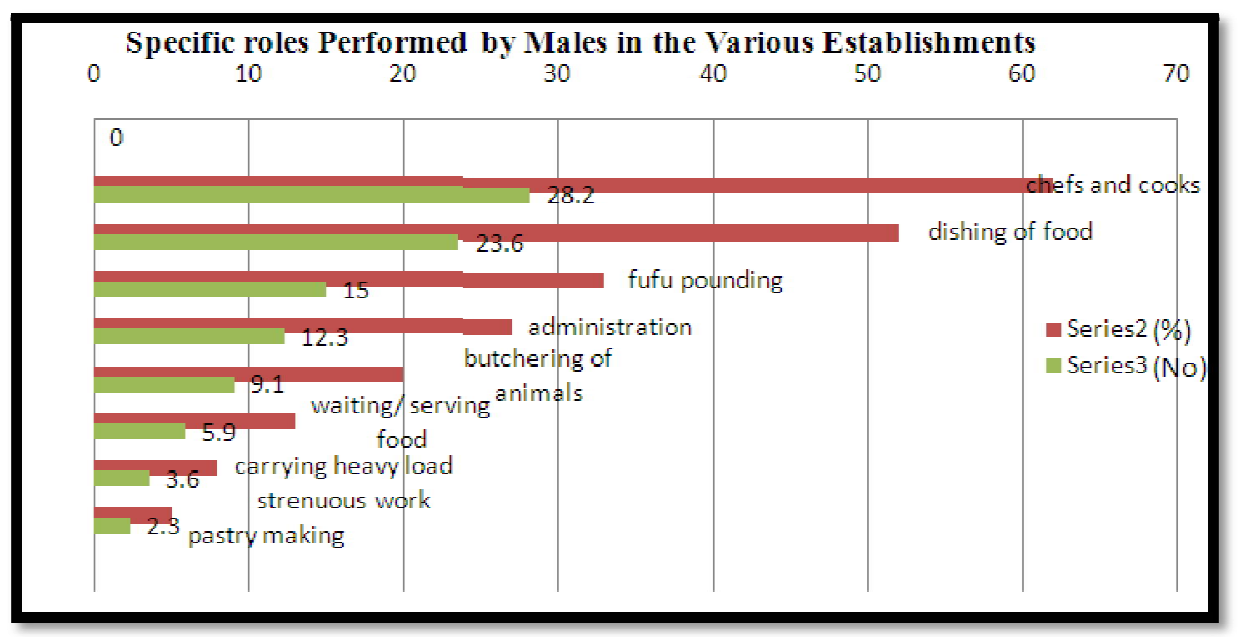

Figure 1: Specific Roles Performed by Males in the Various Establishments in Kasoa a. Multiple Responses

Source: Field Survey, 2016

\subsection{Respondents' Views on Participation of Males in the Catering Industry}

Views sought from the respondents indicated that $73.1 \%$ felt their female colleagues were cooperative, friendly and tolerant towards them while $93.0 \%$ indicated that they received a lot of respect from their female counterparts. All the respondents indicated that they enjoyed their work. The analysis of the views from the 27 employers indicated that, i). 23 (85.2\%) felt male employees were more punctual than their female counterparts; ii). 19 (70.3\%) felt women employees were more obedient than men; and iii). 20 (74.1\%) were of the view that females performed better as waitresses because they were better able to attract customers, particularly the males owing to their appearance. To the remaining seven (25.9\%), the male waiters were smarter and more consistent. All the employers (100\%) said that the male cooks were sometimes shy which made it seemed like they did not enjoy the job they had chosen to do. This shyness stemmed from the stereotyping in the society.

The general deduction on the views expressed by the respondents on participation of males in the catering industry revealed that to the employers, the male cooks were sometimes shy, stemming from the stereotypes of the society. They felt that though the males were more punctual at work, female waitresses attracted customers better than the males. All the respondents attributed the low participation of males in the catering industry to the perception of the society that cooking is for women and also lack of support from the public. The cooks and chefs alleged that even though their female counterparts gave them a lot of encouragement, their male friends in town looked down on them and sometimes called them names, such as "Kodwo Besia (Man Woman)". This may be an indication that the society has not fully accepted the participation of males in catering as normal yet as Oppong (1999) noted.

A summary of the results can be listed as follows: 
- The majority (81.7\%) of males in the sample started participating in the catering industry when they were aged between 20 and 30 years and so they could take their own decisions.

- Out of the 131 respondents, only 15 were qualified for the job since they had had the requisite training in catering.

- External factors such as economic, relatives and courses taken in school and interest, an internal factor, influenced the respondents' choice of catering.

- The major roles of the males with low levels of formal education in the catering industry were cooking and carrying out strenuous activities such as pounding fufu, slaughtering of animals, off-loading and on-loading food and other heavy items from trucks and the premises.

\section{Conclusions}

- In general, it can be concluded that the number of males in the catering industry is still minimal but the fact that $53.6 \%$ performed the roles of chefs and cooks, dished food and prepared pastries indicates that the notion of cooking being a preserve for females can be eroded.

- The choice of the occupation was motivated mainly by external factors, the main one being economic, indicating that the interest of males in catering is still very low.

- Generally, a study of the data indicated that strenuous activities such as fufu pounding and carrying heavy loads were duties performed by males with no or very low levels of education, while those who prepared pastries were those who HND, City and Guilds and NVTI certificates. Higher education improved the status of the males in the industry.

- Views expressed by the employers and the male respondents themselves indicated that there is still the perception that catering, as a job, was for women although the male respondents were of the view that that perception should be erased.

\section{Recommendations}

- Males should be actively involved in cooking at home right from their infancy. This will help them to gain firsthand experience and also develop interest.

- Parents should not prevent their male children who want to take up catering in schools from doing so.

- Interest for catering can be created in males through catering clubs and cooking competitions by heads, teachers and the mass media.

- Public education should be carried out in churches and town halls.

- Guidance and Counselling Coordinators in schools should avoid restricting males to specific courses leaving out catering and sewing.

- Special scholarships must be set aside for males in catering by the government.

\section{References}

i. Amedahe, F. K. (2005). Attitudes of basic education teachers towards the use of continuous assessment in Ghana. Journal of Institute of Education, 3 (1), 8 - 20

ii. Banner, L. W. (1999). Why women have not been great chefs. The Southern Atlantic Quarterly. Spring.

iii. Bierstadt, R. (2000). The social order. New York: Basic Books Publishers.

iv. Best, J. W., \& Kahn, J. V. (1996). Research in education. (7th Edition). New Delhi: Prentice Hall.

v. Blood, R. O., \& Wolfe, D. M. (1997). Husbands and wives: The dynamics of married living. London: Collier, Macmillan Ltd.

vi. Cook, E. P. (1995). Role salience and multiple roles: A gender perspective. Career Development Quarterly.

vii. Granfield, G. (1996). Sex on the brain. The Times Higher Education Supplement.

viii. Hardiman, W.K. (1990). Traditional Ghanaian women. London: Collier, Macmillan.

ix. I.L.O./JASPA (1993). Development policies and institutional environment for employment promotion in the informal sector in Ghana. I.L.O. Publication. Geneva.

x. MacArthur, R. L. (2008). Compliance with food safety measures by traditional caterers in the Cape Coast metropolis. Unpublished M.Phil. Thesis, University of Cape Coast.

xi. Mackenzie, J. (1997). It's a man's job: Class and gender in school work experience programmes. Edinburgh: SCRE. CCC.

xii. Narayan, S. (2001). Where the kitchen is mostly a man's club. New York: New York Times 2. 23

xiii. National Analytical Report: (exploringafrica.matrix.msu.edu.) accessed on November $4^{\text {th }} 2015$.

xiv. National Restaurant Association (2003). Restaurants. http:/ / www. restaurant.org. (Accessed on 12/ 10/2015)

xv. Nweke, C., \& Anagbogu, M. (1989). Career choice and information. In C. Nweke. Guidance and counselling: Principles and practice. Nsukka: University of Nigeria Press

xvi. Nyamwange, J. (2016). Influence of student's interest on career choice among first year university students in public and private universities in Kisii County, Kenya Masai. Journal of Education and Practicewww.iiste.org ISSN 2222-1735 (Paper) ISSN 2222-288X (Online) Vol.7, No.4, 201696

xvii. Nyasulu, T. U. (2012). Governance and customary land tenure in per-urban Kasoa in Ghana.

xviii. Oppong, C. (2004). Domestic rights and duties in Southern Ghana. Legon Research Paper No. 1. University of Ghana: Institute of African Studies. 
xix. Owusu, M. A., Brew, E. M., Ampiaw, R. E., \& Dadzie, J. (2016). Gender inequality in TVET institutions, bridging the gap: The case of Accra Polytechnic. Mathematical Theory and Modeling www iiste.org ISSN 2224-5804 (Paper) ISSN 2225-0522 (Online) Vol.6, No.1, 201627

xx. Perera, J., \& Velummayilum, P. (2008). Women's career choice and gender roles: A South Asian experience. The Clinical Teacher, 5: 186-190.

xxi. Point, F. (1990). American cookery. New York: Bedford, Massachusetts.

xxii. Singh, K., Granville, M., \& Dika, S. (2002). Mathematics and Science Achievement: Effects of Motivation, Interest, and Academic Engagement. The Journal of Educational Research, 95(6), 323-332.

xxiii. Smith, P. (2000). Daughters of the Promised Land: Women in American history. Boston: Boston University Press.

xxiv. Smith, J. L., \& White, P. H. (2007). The stereotyped task engagement process: The role of interest and achievement motivation. Journal of Educational Psychology, 99, 99-114.

xxv. Stangor, C. (2014). Research method methods for the behavioural sciences (5th Ed.). New York: Cengage Learning

xxvi. Vosh, J. F., \& Schauble, L. (2014). Is interest educationally interesting? An interest related model of learning. In K. A. Runninger, S. Hidi \& A. Krapp (2014), pp.101-120). The role of interest in learning and development. New York: Psychology Press.

xxvii. Watt, H. M. G., \& Eccles, J. S. (Eds.). (2008). Gender and occupational outcomes: Longitudinal assessments of individual, social, and cultural influences. Washington, DC: American Psychological Association.

xxviii. Watt, H. G. M. (2010). Gender and occupational choice. Retrieved on 19 August 2016 https:/ / www.researchgate.net/ publication/ 226732843DOI: 10.1007/ 978-1-4419-1467-5 16.

xxix. Wikipedia, the free encyclopedia: Kasoa

xxx. "World Gazetteer online". World-gazetteer.com. (Archived from the original on 2012-01-11).

xxxi. Yankson, P. W. K, (2012). Landlordism and housing production in Greater Accra Metropolitan Accra. In: ArdayfioSchandorf, Yankson, P.W.K., \& Bertrand, M. (Eds.). The mobile city of Accra: urban families, housing and residential practices. Dakar, Senegal, CODESRIA. 